\title{
Founders, Shakers, Prime Movers
}

\section{Who Were Those Guys?}

While reflecting on the histories and trajectories of the 36 researched companies, it became clear early on that the personalities involved in the creation of these firms played a special role in the firms' histories and eventual successes. Thus, not only were the founders' own backgrounds tracked but so were the firms' formation, as well as the working relationship these individuals had prior to the companies' creation.

Given that the individual stories not only differed for each company, in addition to the era in which they were founded, the founders were grouped into several different periods. Because the oldest firms were more than 125 -years old, the experience of those founders, and their origins, could not be compared to the companies formed in later periods.

The selected time periods:

- The Early Founders: Pre-World War I (WWI)—six companies

- Interwar Depression Period: Between World War I and World War II (WWII) six companies

- The Period of World War II-five companies

- Post-World War II "Baby Boomer” Period 1945-1980-15 companies

- The Newcomers Recent Period Late twentieth Century-four companies

At the time of this writing, all of these firms were in continuous operation and all but the most recent have changed hands in terms of management and ownership.

The changing histories of these companies also meant that other movers and shakers were involved; attention needs to be paid to the prime movers who were the most important in terms of moving the companies toward their eventual trajectory. Consequently, some additional space is devoted to prime movers, in order to differentiate them from founders (Tables 2.1 and 2.2). 
Table 2.1 List of founders

\begin{tabular}{|c|c|c|}
\hline Start company name & Activity & Founder \\
\hline 1833 Sefar & Weaving & Pierre Dufour \\
\hline $\begin{array}{l}1844 \text { Burckhardt } \\
\text { Compression }\end{array}$ & Compressors & Franz Burckhardt \\
\hline $\begin{array}{l}1851 \text { Geistlich } \\
\text { Pharma }\end{array}$ & Bioscience & Heinrich Geistlich \\
\hline 1879 Sécheron & Transformers & de Meron/Thury \\
\hline $\begin{array}{l}1885 \text { Cendres } \\
+ \text { Métaux }(\mathrm{C}+\mathrm{M})\end{array}$ & Parts manufacturing & Louis Aufranc \\
\hline 1886 Lantal Textiles & Textiles/Weaving & Friedrich Baumann and Albert Brand \\
\hline 1908 Max Felchlin & Chocolate & Max Felchlin \\
\hline 1923 Plumettaz & $\begin{array}{l}\text { Cable laying } \\
\text { machinery }\end{array}$ & Emile Plumettaz \\
\hline 1924 Caran d'Ache & Writing Instruments & Arnold Schweitzer \\
\hline 1925 Kuhn Rikon & Cooking pans & Heinrich Kuhn \\
\hline 1930 Ricola & Herbal candy & Emil Richterich \\
\hline 1931 Jura & Espresso machines & Leo Henzirohs \\
\hline 1934 Fraisa & Cutting tools & Johann Stüdeli \\
\hline 1938 Filtrox & Depth filtration & Hans Schmid \\
\hline 1939 Pilatus Aircraft & Aircraft & Emil Bührle \\
\hline 1940 DC Swiss & Threading tools & Daniel Charpillot \\
\hline 1942 Oetiker Group & Connectors & Hans Oetiker \\
\hline 1942 Rüeger & Measurement & Ernst Rüeger \\
\hline 1945 FELCO & Pruning shears & Felix Flisch \\
\hline $1947 \mathrm{EAO}$ & Control buttons & Kurt Loosli and René Thalmann \\
\hline 1956 Selectron & Train controls & Paul Stegmann \\
\hline 1956 Plaston & $\begin{array}{l}\text { Packaging } \\
\text { containers }\end{array}$ & Hans Frei \\
\hline 1957 FISBA & Optical components & $\begin{array}{l}\text { Waldemar Striezel, Hennoch Altherr and } \\
\text { Christian Fischbacher }\end{array}$ \\
\hline 1961 maxon & Electric motors & Braun Family \\
\hline 1969 Sylvac & Measuring systems & Hans Meyer and Urs Schnyder \\
\hline 1971 Bachem & Peptides & Peter Grogg \\
\hline 1972 LEM & $\begin{array}{l}\text { Electric } \\
\text { measurement }\end{array}$ & Jean-Pierre Etter \\
\hline 1973 Acutronic & Motion simulators & Leo Marxer \\
\hline 1973 LNS & Bar feeders & $\begin{array}{l}\text { André Léchot, Walter Neukomm and Maurice } \\
\text { Scemama }\end{array}$ \\
\hline 1974 Thermoplan & Coffee machines & Domenic Steiner \\
\hline 1975 Komax & Cabling machinery & Max Koch \\
\hline 1981 Mikrop & Optical components & Gerhardt Machleidt and Erhart Müller \\
\hline 1988 Datamars & RFID solutions & Audemars, Datalogic \\
\hline
\end{tabular}


Table 2.1 (continued)

\begin{tabular}{l|l|l}
\hline Start company name & Activity & Founder \\
\hline 1997 Medartis & Medical implants & Thomas Straumann and Willy Miesch \\
\hline 1997 u-blox & Positioning systems & $\begin{array}{l}\text { Daniel Ammann, Andreas Thiel and Jean- } \\
\text { Pierre Wyss }\end{array}$ \\
\hline 1999 Wyon & Batteries & Paul Wyser \\
\hline
\end{tabular}

Source: Compiled by Authors

Table 2.2 Founders

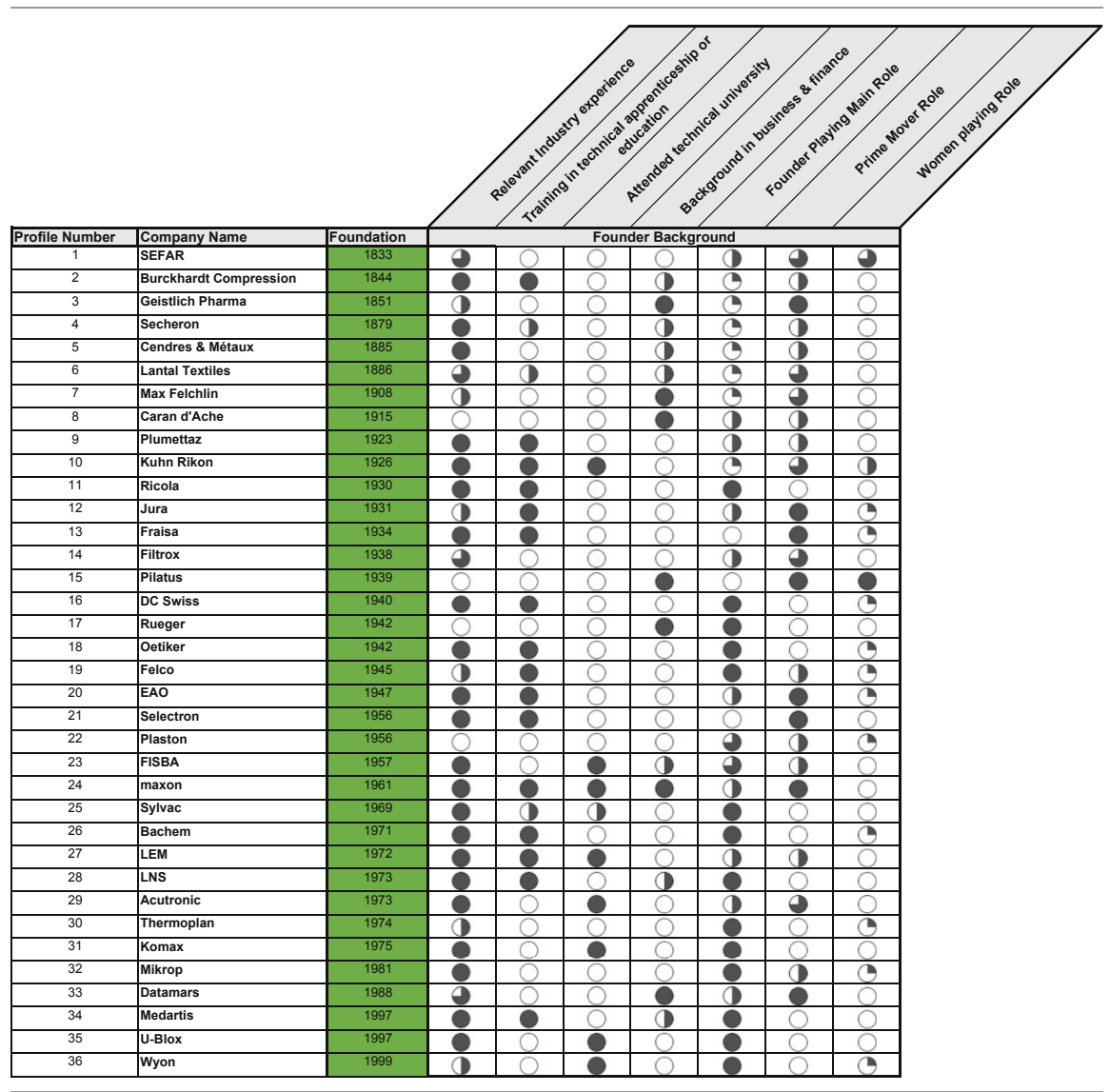

Source: Table Compiled by Authors 


\section{Founders from the Early Period}

The histories of firms, which are still operating after more than 125 years show that founders have taken one of two approaches: the first by operating as single owners who capitalized on their own technical skills, and the second by having teamed up with technical talent.

A group of the early founders were single entrepreneurs who started small businesses, or workshops, based on their skills and then grew the enterprise over time, usually turning the companies over to a second generation to promote growth.

- Pierre Dufour, an expert in silk weaving, separated from the Zurich family Bodmer who had a long history in silk trading, to create his own silk gauze weaving company in Thal, in 1833, which was to become Sefar.

- In Basel, Franz Burckhardt started a mechanical workshop, in 1844. Today it is Burckhardt Compression.

- Heinrich Geistlich created his company Geistlich in Zurich, in 1851, collecting bones from slaughterhouses to turn them into glue.

- In 1885, pharmacist Louis Aufranc started what became Cendres + Métaux (C +M) in the back of his Biel/Bienne pharmacy, melting gold and silver left over by watchmakers, remains there were meant to be reused.

The technical backgrounds of these early founders were based on accumulated experience, not from formal technical training. They were problem solvers and developed their products through trial and error but also had a clear understanding that their innovations were needed.

Given the scarcity of capital at that time, a second pattern emerged from studying these early companies: entrepreneurs with financial resources teaming up with a gifted technical person who brought their know-how to the venture.

- Along these lines, Geneva businessman Alfred de Meron worked with René Thury, a gifted engineer, in 1879, to start what today is known as Sécheron.

- In Langenthal, Friedrich Baumann, having a background in textile trading, found his partner Albert Brand to start in 1886 what is now Lantal Textiles.

At the time, it was the nature of the situation that the early founders were able to bring the companies only so far and that major growth in all of these firms occurred in subsequent periods, usually more than a generation removed. Often, these companies were transferred to later owner generations, becoming family companies. At the time of their creation, however, there was no such plan and no indication that the early founders worked off a blueprint or even a business plan as is known today. Some of the early founders would probably be surprised at how large their ventures turned out to be. 


\section{Founders from the Interwar Period (WWI to WWII)}

Looking at the companies created during this interwar period, largely impacted by the experience of a global recession that also touched Switzerland, the founders confronted a very different economic situation. Not to be deterred, these founders started business and saw opportunities where others hesitated, and in some cases were told that they were literally nuts to undertake the effort. On one hand, this was an uncertain period when people valued security above all else and did not engage in risky ventures. On the other hand, the hard economic time drove a number of companies into bankruptcy, which became acquisition targets for those willing to venture out. These founders did not continue with their previous businesses but used old assets, such as workshops, as the basis from which to move forward with innovations into various sectors.

Above all, the founders at that time were all skilled craftsmen who had often gone through the Swiss apprentice system, the dual educational system where young people left school at around 15 or 16 years of age to learn a trade through a 3 - or 4-year apprenticeship. They all came from families of modest financial means.

- In 1923, at the age of 38, Emile Plumettaz founded Plumettaz, leaving a secure job at Nestlé to start his mechanical workshop.

- Heinrich Kuhn, a mechanical engineer, returning from France, acquired the workshop that was to become Kuhn-Rikon in 1925.

- A master baker and confectioner, Emil Richterich started his bakery shop in 1930 at the age of 23 which became Ricola.

- Electrician Leo Henzirohs, at age 29, started his workshop in order to build electrical appliances in 1931 and grew it to Jura Elektroapparate.

- Metal tool mechanic Johann Stüdeli, at the age of 46, acquired part of a bankrupt operation in 1934 and built it into Fraisa.

Different were the backgrounds of two founders who had their roots in commerce and finance.

- Max Felchlin, educated in commerce, began a honey trading business in 1908 at just 25 years old. His eventual food processing business, which was also started post-WWI, grew into a flourishing business still bearing the name Max Felchlin.

- In 1924, a group of local Geneva investors, under the leadership of Arnold Schweitzer, took over a distressed pencil company that had entered bankruptcy to start a new firm that is now Caran d'Ache.

\section{Founders Creating Businesses During WWII}

The period of WWII was a time of scarcity and deprivation in Switzerland, despite the fact that the country was not directly involved in the war. International trade was disrupted and both imports into and exports out of Switzerland were substantially 
curtailed. And yet, during this time there were still some entrepreneurs willing to start businesses of a lasting nature.

- Anticipating the disruption of the coming political crisis in Europe, Hans Schmid, working as a Swiss sales representative for a German company, created Filtrox in 1938 by acquiring an old textile plant in Eastern Switzerland.

- In 1939, following the suggestion of the Swiss government, industrialist Emil Bührle created Pilatus to service Swiss army aircraft.

- In the Jura, Daniel Charpillot, a mechanic and toolmaker, left his family business in 1940 to start on his own enterprise, creating what became DC Swiss.

- In the Zurich area, Hans Oetiker left his position as a toolmaker with Brown Boveri (today he would be called a polymechanic) in 1942, at the age of 24 , to start out on his own and create what would become Oetiker Group.

- In 1942, Ernst Rüeger moved from Basel to Lausanne to be further away from the area where he met Georges Bloch, an engineer, and created the Rüeger company, based on Bloch's invention.

Of these founders, only Oetiker came from a family of modest financial means. The others, through either past business experience or family backgrounds, already had access to capital in order to start their businesses.

\section{Founders from the Post-WWII "Baby Boomer" Generation}

The post-WWII period in Switzerland was characterized by rapid economic growth. This period saw the emergence of many of the researched companies. Most of them grew rapidly and exceeded a size normally considered typical for an SME.

- Felix Flisch, a mechanic, founded his company at the age of 31, in 1945, making pruning shears in the Neuchatel Jura; the company later became known as Felco.

- In 1947, Kurt Loosli and René Thalmann, two 26-year-old polymechanic engineers, founded EAO in Olten, producing transformers for trains and electrical cabinets.

- Hans Frei left his employer in 1956, at the age of 55, due to health reasons and started Plaston, near St. Gallen.

- In Lyss, Paul Stegmann, a technically oriented businessman, started Selectron in 1956, producing electronic controls.

- Christian Fischbacher, a business owner from St. Gallen with a background in the textile industry, Hennoch (Heni) Altherr and Waldemar Striezel, both optical engineers, opened FISBA to make optical components in 1957.

- In Sachseln, the Braun family, successful industrialists originating from Germany, started a component business for electric shavers in 1961 that became maxon. 
- In 1969, the two fine mechanics Hans Meyer and Urs Schnyder combined their operations to form Sylvac, in both Renens and the Jura Bernois, making industrial measurement devices.

- A 29-year-old chemistry lab technician Peter Grogg started Bachem, near Basel, by selling peptides to the pharmaceutical industry in 1971.

- Jean-Pierre Etter, an electrical engineer with an interest in physics, created LEM in Geneva in 1972. He was 37 years of age and had previously worked for Brown Boveri, as well as having started an engineering business.

- Leo Marxer, an engineer, founded Acutronic in 1973, entering the simulation field because he could not get his US supplier to adapt the equipment to local requirements.

- LNS was created in 1973 by André Léchot, an engineer who ran his own mechanical workshop in the Jura Bernois, together with two business associates, Walter Neukomm and Maurice Scemama, who helped scale the company, which produced innovative bar feeders for automatic machining centers.

- Thermoplan was founded in 1974 by Domenic Steiner who had left his position as stationmaster for the Swiss Railways to become an entrepreneur without a clear business plan. The idea to build automatic espresso coffee machines came later.

- Max Koch graduated from the Swiss Federal Institute of Zurich (ETH Zurich) to create Komax in 1975, in order to follow up on an earlier idea to make the joining of electric cables more efficient.

- Gerhardt Machleidt and Erhart Müller, both optical engineers, left their employer in 1981 to create Mikrop, offering improved optical equipment.

The majority of these founders had technical backgrounds relevant to the industry sectors they entered. Among those starting up immediately after WWII, completing an apprenticeship was the usual step to take in order to acquire the necessary background in a technical formation. In later years, engineering backgrounds became largely based on the education at today's University of Applied Sciences (Technikum). Some founders, like Max Koch who graduated from ETH, moved directly from university to create their own companies. In general, these founders were still in their 20s and their start-ups represented their first business ventures.

There are also family groups-including both the Braun and the Meyer and Schnyder families-who built businesses. Some of these entities were started by later-stage founders who had had previous business careers in their industries or who had owned related companies. The failure of a supplier or an employer to innovate also gave rise to the founding of companies. As witnessed in previous periods, some companies were ventures between inventors and experienced industrialists, which combined capital and business acumen with innovative product ideas.

Possibly the only outlier in this group was Domenic Steiner who left his secure position with the Swiss Federal Railways (SBB) to "become an entrepreneur" without any clear notion as to what to build. His previous experience as station master did not really prepare him for his entrepreneurial endeavors, although he turned out to be most successful at it. 


\section{Founders from the More Recent Era}

The four companies from the most recent era are, by their very nature, the youngest crop of companies included in this research. Their stories, nevertheless, are of great interest because they indicate the most recent company trends in starting up new ventures. At the same time, they show the very diverse nature of the origins of companies and how ideas led to their creation.

- Datamars was created in 1988 as a joint venture between two existing companies, which merged their expertise to form the new firm. Audemars had the collective micromechanical and electronic knowledge of a watch component manufacturer, while Datalogic specialized in bar codes. The new company specialized in radio-frequency identification (RFID) solutions.

- Thomas Straumann and Willy Miesch created Medartis in 1997. It was Straumann's second venture and as a spin-off from Straumann DentalStraumann's first venture that had already grown beyond SME size-focused on medical implants.

- u-blox was created as a start-up in 1997 by three ETH Zurich engineering students, Daniel Ammann, Andreas Thiel, and Jean-Pierre Wyss, who left their Ph.D. program to start the company, whose focus was on providing solutions to connect satellite-based positioning solutions.

- The youngest company in the sample, Wyon, was started in 1999 by Paul Wyser who became disenchanted with his previous employer, the Swatch Group. He convinced his two sons Maurus and Philipp to join him in starting up a company to produce special rechargeable Li-ion batteries.

The pattern of previous founders having utilized deep technical backgrounds and experience for their new ventures repeated itself. Whereas the creation of u-blox reflected the most recent trend to start-out from university, the other examples show that entrepreneurial ventures also can be created in later stages of life, whether as a second venture or by leaving an employer who was not willing to pursue new ideas.

What happens when two polymechanic apprentices combine efforts to create a company is demonstrated by Medartis, the second youngest company in the research. Both Thomas Straumann and Willy Miesch met during their apprenticeship as polymechanics at the Straumann Institute. ${ }^{1}$ They later pooled their experience to manufacture demanding medical implants and create Medartis. By that time, both of them had long since moved beyond the apprenticeship stage and accumulated extensive operational management experience in managing medical implant companies.

\footnotetext{
${ }^{1}$ The term polymechanic is one used more recently in Switzerland, superseding older terminology, such as precision mechanic or fine mechanic.
} 


\section{Differentiating Between Prime Movers and Founders}

A major impulse for the growth and development of a company need not come from the founders alone. Although the original founders played key roles in creating the companies, in many situations, and particularly when considering a longer time frame, other personalities stepped in and either redirected a company's strategic trajectory or resurrected it and rescued it from failure.

One of the more telling examples of founder versus prime mover is offered by Selectron. Founded in 1956 by a technically oriented entrepreneur, the company soon reached sales of CHF 30 million by producing electronic devices to drive machine tools. With its products losing out against larger international firms, the company went through a period of declining sales, accumulating losses. Passing through several hands, the company was acquired by a large international firm, which in fact, had no use for it. Tasked to liquidate the company "without creating any waves", Emmanuel Hannart discovered that the company had some neglected and unappreciated technical strength. Focusing on the barely noticed segment of in-train electronic controls, this small segment grew into a sizeable and sustainable firm, turning in healthy profits and growth rates. Clearly, without the leadership of Hannart, Selectron would have been liquidated and its assets sold off. The entire process is detailed in the Selectron company profile. ${ }^{2}$

Other companies fit a similar pattern. A team of internal and external managers brought Pilatus back to a profitable and sustainable growth path. Burckhardt Compression was acquired through a management buyout (MBO) and turned into a growing company with healthy returns. Likewise, LEM was refocused by a new team on the company's board. Sécheron was resurrected by a team of outside managers with deep industry experience who had acquired the company from its financial owners. Due to the importance of this process of resurrection, a special section is devoted to the topic later in the book.

\section{Reflecting on the Background of Founders}

Reviewing the list of firms, their founders, as well as the circumstances of their backgrounds, a number of factors stand out.

First and foremost, the founders had in-depth knowledge of the industry or application relevant to their ventures. Many of them, particularly in the earlier phase, gained this expertise through practical apprentice-type programs. Secondly, these founders were young, many of them below the age of 30, and had started with small operations, gradually building them into bigger companies. Most of these founders came from modest financial backgrounds.

A second group of founders leveraged their industry experience gained through businesses selling to a particular target industry segment. They capitalized on their

\footnotetext{
${ }^{2}$ Adapted from Selectron company profile.
} 
realization that improvements to the status quo would sell well. To make up for a lack of engineering or technical skills in manufacturing, they often teamed up with gifted and experienced engineers to bridge the gap. Drawing on financial resources available from their previous careers, this group of entrepreneurs was able to acquire firms that had gone into bankruptcy.

Teams, taking over operating companies in financial distress with an interest in putting them back on a growth path, had accumulated considerable industry and management experience prior to taking over the distressed firm. Those teams usually had a technical background as well. Since such developments occurred in more recent times, their technical training was often university-based rather than stemming from practice-oriented apprenticeships.

\section{And Women?}

Scanning the list of the founders from the 36 companies researched, the reader will quickly notice the absence of any women. One possible explanation is that exporting companies often dealt with technology products requiring engineering and manufacturing skills. Traditionally, few women were found in those occupations. Another explanation is that some of the companies researched began operations a long time ago. This naturally disadvantaged women who only in recent years have become represented in larger numbers within these occupations. However, there were some remarkable examples of women found in the research who played significant roles in building companies upon the death of their founder husbands.

A leading role was played by the widow of a company founder relating to the oldest documented company, Sefar. The company was founded by Pierre Dufour in 1833 as a silk gauze weaving operation. When the founder died unexpectantly in 1842 , he left the company to his 25-year-old widow, Anne-Joséphine DufourOnofrio, and their infant son. Like her husband, Mrs. Dufour came from Lyon and her family was also in the silk business there. Contrary to everyone's expectation that she would return to Lyon, she instead took over the company and remained in the small town of Thal in the St. Gallen Rhine Valley. Under her management, Dufour \& Co. grew to become the dominant silk gauze weaving company, employing more than 1000 people at the time of her death at the age of 84 , in $1901 .^{3}$

In many firms, spouses and daughters played significant roles behind the scenes, sometimes assuming operation roles or by supporting major investments involving family resources.

At Plaston, efficient operation of an injection molding machine demanded uninterrupted 24-h use. The four-member start-up team taking up this challenge, in addition to founder Hans Frei, included his wife Sofia, son Roland and daughter Madlen. Father Hans and son Roland would run production and sell products while

\footnotetext{
${ }^{3}$ Adapted from Sefar company profile.
} 
Sofia and Madlen handled the bookkeeping and looked after the machine during breaks. ${ }^{4}$

As companies matured and initial founders stepped down, in a number of instances, daughters assumed leadership roles as board chairs. Such was the case at Caran d'Ache and Kuhn Rikon, or they became board members, as was the case at both maxon and Fraisa.

Open Access This chapter is licensed under the terms of the Creative Commons Attribution 4.0 International License (http://creativecommons.org/licenses/by/4.0/), which permits use, sharing, adaptation, distribution and reproduction in any medium or format, as long as you give appropriate credit to the original author(s) and the source, provide a link to the Creative Commons license and indicate if changes were made.

The images or other third party material in this chapter are included in the chapter's Creative Commons license, unless indicated otherwise in a credit line to the material. If material is not included in the chapter's Creative Commons license and your intended use is not permitted by statutory regulation or exceeds the permitted use, you will need to obtain permission directly from the copyright holder.

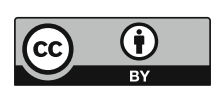

\footnotetext{
${ }^{4}$ Adapted from Plaston company profile.
} 